\title{
Combined Chemotherapy of Multibacillary Leprosy Patients
}

\author{
N. M. SAMUEL*, S. SAMUEL \\ (Anandaban Leprosy Hospital, Kathmandu, Nepal) \\ R. B. ADIGA \\ (Leprosy Services Development Board, Ministry of Health/HMG. Kathmandu, Nepal)
}

(Received for publication: June 20, 1986)

\begin{abstract}
Key words : Combined chemotherapy, Drug resistance, Relapse, Morphological and bacteriological indices
\end{abstract}

\begin{abstract}
380 multibacillary leprosy patients were treated with combined chemotherapy at Anandaban leprosy hospital in Nepal. The drugs used were Rifampicin, Dapsone, Clofazamine and Isoprodian. This treatment is modelled on the short course chemotherapy of tuberculosis. A remarkable clinical and bacteriological improvement was observed in all patients. Group A patients were bacteriologically negative after 24-32 months of treatment and Group B patients were skin smear positive even after 36 months of treatment. However, patients in Group C, who received five drugs, showed marked clinical and bacteriological improvement. Discolouration caused by Clofazamine did not lead to interruption of treatment. We found the drug regimens safe, effective and economical.
\end{abstract}

\section{Introduction}

The widespread emergence of dapsone resistance $\left({ }^{1}\right)$ has emphasised the necessity of using combinations of at least three antileprosy drugs for the treatment of lepromatous leprosy. Of the drugs available for use in combination with dapsone, rifampicin with its rapid bactericidal activity is the first choice $\left({ }^{2}\right)$. Clofazamine is less costly than rifampicin, and its antileprosy activity is of the same order as that of dapsone $\left(^{3}\right)$. Thioamides are another group of drugs with antileprosy activity $\left({ }^{4}\right)$. It has been suggested $\left({ }^{5}\right)$ that combination of drugs for a short period in the field conditions will be the best approach for leprosy control and for the interruption of the transmission of $M$. leprae in the community. Since 1981 combined drug regimens have been used in treating leprosy patients under our care at Anandaban leprosy hospital in Nepal $\left({ }^{6}\right)$. This paper focuses mainly on the 380 multibacillary leprosy patients treatment with combined therapy, their follow up evaluated clinically and bacteriologically.

* Correspondence to Dr. N. M. Samuel, Department of Microbiology, Cardiothoracic Institute, Fulham Road, London SW3 6HP. 


\section{Materials and Methods}

For each patient under treatment, a case history was taken and clinical and bacteriological examinations were performed and recorded on standard clinical multidrug treatment $\left({ }^{7}\right)$ files. Patients were classified on the Ridley-Jopling scale $\left({ }^{8}\right)$ : in a majority a lepromin test was performed and a skin biopsy was taken to confirm the diagnosis. The 380 patients were distributed as shown in Table 1.

\section{Laboratory investigations :}

1. Skin smears were taken by the slit and scrape method from both ear lobes and from two other sites for bacteriological and morphological indices $\left({ }^{9}\right)$. These were performed on the day of the initial clinical examinations and at six months intervals.

2. Skin biopsies were taken from the active lesions prior to therapy and at intervals of six months during the treatment period. These were processed in the routine manner for histopathology $\left({ }^{10}\right)$.

3. Lepromin A (Armadillo derived) $0.1 \mathrm{ml}$ of $2 \times 10^{6}$ cobalt irradiated bacilli per $\mathrm{ml}$, was injected intradermally into the upper outer aspect of right arm. Reading was in $\mathrm{mm}$ of induration and was performed at 21 or 28 days. Two $\mathrm{mm}$ or less in diameter of induration was considered to be a negative reaction.

4. Mouse foot pad tests were performed in locally bred Swiss Albino and nude mice $\left.{ }^{15}\right)$. They were inoculated in both hind foot pads with $M$. leprae isolated from skin biopsies of several patients for drug sensitivity studies. Preparation of the inoculum, inoculation of mice and harvesting of $M$. leprae from the footpad tissues were accomplished by the method of Rees $\left({ }^{11}\right)$.

Table 1 Distribution of patients the drug regimen

\begin{tabular}{|c|c|c|c|}
\hline & Group & Number & Treatment \\
\hline A & $\begin{array}{l}\text { Old patients with } \\
\text { history of past, } \\
\text { partial treatment. }\end{array}$ & $82(22 \%)$ & $\begin{array}{l}\text { 1. Dapsone- } 100 \mathrm{mg} \text { daily } \\
\text { 2. Clofazimine-100 mg daily } \\
\text { 3. Rifampicin } 600 \mathrm{on} \text { two successive days each } \\
\text { month. }\end{array}$ \\
\hline $\mathrm{B}$ & New patients & $245(64 \%)$ & $\begin{array}{lll}\prime \prime & \prime \prime & \prime \prime\end{array}$ \\
\hline $\mathrm{C}$ & New patients & $26(7 \%)$ & $\begin{array}{l}\text { 1. Isoprodian- } 2 \text { tablets (Each tablet consisted } \\
\text { Dapsone } 50 \mathrm{mg} \text {, Prothionamide } 175 \mathrm{mg} \text {, Isoniazid } \\
175 \mathrm{mg} \text { ). } \\
\text { 2. Clofazimine } 100 \mathrm{mg} \text { daily } \\
\text { 3. Rifampicin } 600 \mathrm{mg} \text { on two successive days each } \\
\text { month. }\end{array}$ \\
\hline $\mathrm{D}$ & Absconders & $27(7 \%)$ & $\begin{array}{l}\text { 1. Dapsone-100 mg daily } \\
\text { 2. Clofazimine-100 mg daily } \\
\text { 3. Rifampicin } 600 \mathrm{mg} \text { on two successive days each } \\
\text { month. }\end{array}$ \\
\hline
\end{tabular}




\section{Results}

The distribution of patients according to sex and classification of disease is shown in Table 2. All patients were skin tested with lepromin and the test was negative in all the study subjects. The analysis of the histopathological changes will be reported in another communication.

Clinical and bacteriological evaluation

A marked clinical improvement was observed in all patients. The nasal congestion and the swelling of the feet and hands was remarkedly diminished. The changes in the leprous lesions were characteristic: a flattening of the lesions was observed and the initial erythema and oedema which accompanied the lesions was noticeably absent.

The results of the morphological indices (MI) before initiation of therapy and at the time of evaluation is shown in Table 3 . In group A patients who had previous therapy the administration of combined therapy resulted by six months for morphological indices to be negative. In groups $\mathrm{B}$ and $\mathrm{C}$ by eight months the morphological indices were negative.

The bacteriological changes observed and the months of treatment are shown in Table 4 . In group A, 32 (39\%) patients initial BI was 2.8 and after 24 months of treatment it was negative. Similarly 50 patients $(61 \%)$ with initial BI of 3.2 were negative after 32 months of treatment. This suggests that multibacillary patients who had previous treatment with montherapy will do well with a course of combined chemotherapy for the elimination of bacilli from the skin.

In group $\mathrm{B}$ all 11 mid-borderline patients with $\mathrm{BI}$ negative after 22 months of combined therapy.

Three patients developed mild ulnar neuritis after 15 months of therapy. They were hospitalised and treated with steroids. The bacteriological changes observed in BL and LL patients is noteworthy. Among BL patients, $88(62 \%)$ after 36 months of therapy were BI $1+$; 48 (34\%) after 40 months of chemotherapy the bacteriological indices dropped to $2+$; and 5 (4\%) patients remained BI $3+$ even after 42 months of therapy. The BI changes seen in LL patients is as follows: in 26 patients $(28 \%)$ the $\mathrm{BI}$ was $2+$ after 42 months of therapy; in 6 patients $(6 \%)$ the BI was $1+$ after 36 months of treatment; and in $37(40 \%)$ there were high bacterial counts in the skin of the patients even after treatment for 36 months. In 24 (26\%) $\mathrm{LL}$ patients the $\mathrm{BI}$ was $4+$. This suggests that chemotherapy alone may perhaps be inadequate 
Table 4 Showing the months of combined chemotherapy and the bacteriological status at the time of evaluation

\begin{tabular}{|c|c|c|c|c|c|c|}
\hline \multirow{2}{*}{\multicolumn{2}{|c|}{$\begin{array}{l}\text { Group and } \\
\text { type }\end{array}$}} & \multirow{3}{*}{$\begin{array}{c}\text { No. of patients } \\
32(39 \%)\end{array}$} & \multirow{3}{*}{$\begin{array}{c}\begin{array}{c}\text { Pretreatment } \\
\text { (average) }\end{array} \\
2.8\end{array}$} & \multicolumn{3}{|c|}{ At the time of evaluation. } \\
\hline & & & & \multicolumn{2}{|c|}{$\begin{array}{l}\text { Number of months of } \\
\text { combined therapy }\end{array}$} & \multirow{2}{*}{$\begin{array}{l}\text { Bacteriological } \\
\text { Index }(\mathrm{BI}) \\
\text { (average) }\end{array}$} \\
\hline A & $\mathrm{BL}$ & & & & 24 & \\
\hline & LL & $50(61 \%)$ & 3.2 & & 32 & 0 \\
\hline \multirow[t]{8}{*}{ B } & $\mathrm{BB}$ & 11 & 2.6 & Pts \% & 22 & 0 \\
\hline & $\mathrm{BL}$ & 141 & 4.7 & $88(62 \%)$ & 36 & $1+$ \\
\hline & & & & $48(34 \%)$ & 40 & $2+$ \\
\hline & & & & $5(4 \%)$ & 42 & $3+$ \\
\hline & LL & 93 & 5.3 & $6(6 \%)$ & 36 & $1+$ \\
\hline & & & & $26(28 \%)$ & 42 & $2+$ \\
\hline & & & & $37(40 \%)$ & 36 & $3+$ \\
\hline & & & & $24(26 \%)$ & 24 & $4+$ \\
\hline C & LL & 26 & 4.3 & & 26 & 1.6 \\
\hline \multirow[t]{2}{*}{$\mathrm{D}$} & $\mathrm{BL}$ & 7 & 3.6 & & 3 & \\
\hline & LL & 20 & 3.8 & & 7 & Not recorded \\
\hline
\end{tabular}

in multibacillary leprosy to eliminate dead bacilli from the skin of these patients.

The bacteriological changes observed in group $\mathrm{C}$ patients were remarkable. These patients were treated with five anti-leprosy drugs. After 26 months of therapy the BI had dropped from a BI of 4.3 to 1.6.

The multibacillary patients in group $\mathrm{D}$ were irregular on treatment. All the 20 patients tested on the mouse footpad showed dapsone resistance i. e. 12 were primary and 8 were secondary. All efforts to follow up these patients failed.

\section{Adverse effects}

Clofazimine was tolerated by all patients in the study. It induced pigmentation in all patients. The pigmentation was variable between light grey initially to pronounced blackish pigmentation. Two patients of group B were diagnosed clinically to have infective hepatitis. In group $\mathrm{C}$ five patients complained of gastritis and two suffered hepatitis. No other side effects attributable to the drugs were observed.

\section{Discussion}

There have been several major landmarks in the chemotherapy of leprosy. The first was the introduction of dapsone and its anticipated impact on leprosy control. The second was the discovery of clofazimine $\left({ }^{12}\right)$ and its use in leprosy treatment. The third was the introduction of the powerful bactericidal drug rifampicin. The fourth was the use of yet another group of antibacterial drugs, the thioamide group and the fifth was the introduction of supervised, intermittent, short duration chemotherapy with combinations of the above drugs. We consider this combined therapy beyond doubt the latest landmark $\left({ }^{5}\right)$ which is modelled on the short course chemotherapy for tuberculosis $\left({ }^{13}\right)$. 
Chemotherapy of leprosy has two purposes: first, the treatment of individual patient and, secondly, the control of leprosy in the community by interrupting the transmission of M. leprae. Most of the leprosy patients in Nepal have been treated with dapsone monotherapy $\left({ }^{14}\right)$. Due to the lack of basic health infra-structures, the treatment with dapsone has not been successful. Both primary and secondary dapsone resistance has been detected by using the mouse tootpad tests $\left({ }^{15,16}\right)$. Previous reports have shown that the combined chemotherapy is acceptable by patients and lead to increase in patient compliance $\left({ }^{17}\right)$. It is also anticipated that with combined chemotherapy there will be a higher proportion of cure among the multibacillary patients and that the risk of relapse will be reduced.

This paper has shown that 380 multibacillary leprosy patients have been successfully treated with the combination of drugs in Nepal and the clinical and bacteriological results observed are remarkable. The present results have shown that within 24 to 32 months of administration of combined therapy, group A patients obtained negative results in the skin smears. The 11 mid-borderline patients achieved negativity in 22 months of treatment. These patients are probably the most unstable from the immunological point of view The bacteriological observations of patients in group B is that, 36 months of treatment, the skin smears recorded are $1+$. To achieve skin smear negativity in multibacillary patients, it will probably require treatment for up to five years (or more). It is known that, due to the defective immune mechanisms among these patients, the bacilli tend to persist and may contribute to clinical relapse even after cessation of combined treatment. However, the likelihood of relapses occurring in patients who have successiully completed combined therapy is less than those who were given this treatment.

Patients in group $\mathrm{C}$ who received five anti-leprosy drugs showed a more remarkable clinical and bacteriological improvement than patients in group B. We are aware that the number of patients in this group is small but the results observed are promising. A "stronger" regimen might cure a greater proportion of the patients. Contrary to expectations, the incidence and severity of adverse reactions was not significant $\left({ }^{18,19}\right)$. Perpetua et al. $\left({ }^{20}\right)$ suggested only a small proportion of leprosy patients would take combined chemotherpay for more than six months due to either the high cost of treatment or because of the discolouration caused by clofazimine. Twenty-two patients complained that they were recognised by others in the community as leprosy patients because of pigmentation. When information with respect to regression of the dark pigmentation was given, they proceeded to complete the treatment. Discolouration caused by clofazimine did not therefore lead to interruption of the treatment. We found the regimens adopted in this report very effective, sate and fairly economical for the treatment of multibacillary patients. We emphasize the importance of supervision of rifampicin to avert the serious epidemiological problem of ritampicin resistance in leprosy patients $\left({ }^{21,22,23}\right)$. The prospect that we visualize is that at the end of five years or so it may perhaps be possible to remove multibacillary leprosy patients from control with advice to present again for diagnosis and treatment if new lesions occur. Despite the unremitting effects of the governments and non-governmental organizations, the incidence of leprosy has not been decreasing and it is 
still a major public health problem in endemic countries $\left({ }^{24}\right)$.

In summary, although evidence is lacking, these regimens appear likely to be capable of curing a proportion of multibacillary patients but in a small core of patients they are only partially effective. To achieve cure in all, if not in a large proportion, of multibacillary patients effective immunotherapeutic agents may have to be combined with stronger chemotherapy regimens to restore the patients to normality.

\section{Acknowledgements}

We would like to acknowledge the assistance of Dr. R. J. W. Rees, Division of Communicable Diseases, Clinical Research Center, Harrow, London, and Dr. S. K. Noordeen, Chief, Leprosy Unit, WHO, Geneva, for supplying lepromin reagent. We would also like to thank the Leprosy Mission for the drugs and Dr. Wayne Myers, Chief, Armed Forces Institute of Pathology, Washington, USA ; Dr. A. Mukarji, ICMR, Institute of Pathology, New Delhi, India, for their cooperation for histopathological assessment of skin biopsies; and to Dr. John Grange, Department of Microbiology, Cardiothoracic Institute, for encouragement and assistance.

\section{References}

1) Pearson, J. M. H. The problem of dapsone-resistant leprosy. Int. J. Lepr., 44, 417-420, (1981).

2) Leiker, D. L., Kamp, H. First results of treatment of leprosy with rifadin. Lepr. Rev., 41, 25-30, (1970).

3) Sheppard, C. C. Combinations involving dapsone, rifampicin, clofazimine and ethionomide in the treatment of $M$. leprae infections in mice. Int. J. Lepr., 44, 135-139, (1976).

4) Colston, M. J., Hilson, G. R. F. and Banerjee, D. K. The proportional bactericidal test. A method for assessing bactericidal activity of drugs against Mycobacterium leprae in mice. Lepr. Rev., 49, 7-15, (1978).

5) WHO study group. Chemotherapy of leprosy for control programme. Geneva. World Health Organisation Technical Report Series 675, (1982).

6) Samuel, N. M., Samuel, S., Fairbarn, T. and Adiga, R. B. Poly therapy in multibacillary leprosy patients in Nepal. Singapore Med. Journal, 26, 2, 203-206, (1985).

7) Samuel, N. M., Susie Samuel, N. Nakami \& R. Murumu. Multidrug treatment of leprosypractical application in Nepal. Lepr. Rev., 55, 265-272, (1984).

8) Ridley, D. S. and Jopling, W. H. Classification of leprosy according to immunity. A fivegroup system. Int. J. Lepr. 34, 255-273, (1966).

9) Samuel, N. M. Acid fast bacilli in the fingers and toes of long treated lepromatous leprosy. The Asian Medical Jour. Japan, 28, 9, 568-579 (1985).

10) Harman, D. J. Biosies in Leprosy. Leprosy Rev. 46, 125, (1975).

11) Rees, R. J. W. Limited multiplication of acid fast bacilli in the footpads of mice inoculated with Mycobacterium leprae. Brit. J. Exp. Pat. 207-218, (1964).

12) Browne, S. G., Hogerzeil, L. H. B 663 in the treatment of leprosy. Lepr. Rev. 33, 6, (1961).

13) Fox, W. and Mitchison, D. A. Short course chemotherapy for pulmonary tuberculosis. Am. Rev. Res. Dis. 111, 325-353, (1975).

14) Samuel, N. M. Case finding and case holding methodologies in leprosy control in Nepal. The 3rd International Workshop on leprosy control in Asia. Sp-3-Sasakawa Memorial Health Foundation, Tokyo, Japan, Nov. 1980.

15) Samuel, N. M., Samuel, S., Loudon, J. Neupani, K. Adiga, R. B. Prevalence of secondary dapsone resistance in Nepal. Ind. J. Lepr. 56, 4, 823-827, (1984).

16) Samuel, N. M., Samuel, S., Loudon, J. Primary dapsone resistant leprosy in Nepal. Ind. J. Lepr. 56, 4, 819-822, (1984).

17) Samuel, N. M., Samuel, S., Nakami, J. and Murumu, R. Multidrug treatment of leprosy in 
Lalithpur district of Nepal. Jr. Nepal. Med. Ass. 74, 1, 65-74, (1985).

18) Rist, N. Activité anti tuberculeuse de l'ethionamide (L-alpha-ethylthio isonicotinamide ou 1314 Th.) Etude expérimentale et clinique. Adv. Tuberc. Res. 10, 69-126, (1960).

19) Fox, W., Robinson, D. K., Tail, R., Mitchison, D. A., Kent, P. W. and Macfadyen, D. M. A study of the acute intolerance to ethionamide, including a comparison with prothionamide, and of the influence of a Vitamin B-complex additive in prophylaxis. Tubercle, 50, 125-143, (1969).

20) Perpetua, D., Reyes-Javier and Pio, R. Tantiongco. Chemotherapy trial with a triple-drug regimen, including once monthly rimactane (rifampicin) in patients with multibacillary types of leprosy. Acta Leprologica Vol. 1. No. 3. 133-141, (1983).

21) Hastings, R. C. and Jacobson, R. R. Rifampicin resistant leprosy. In : Health Cooperation Papers, pp. 47-54, (1981).

22) Guelpa-claire-Cecile, Grosset, T., Constant Desportes, M. Brucker, G. Nine cases of rifampicin resistant leprosy. Int. J. Lepr. 52, 101-102, (1984).

23) Constant Desportes, M. J. L. Cartel, C. C., Guelpa, C. C., J. Grosset. Primary and acquired resistance of daspone and rifampicin of $M$. leprae in Martinique and Guadeloupe. Ind. J. Lepr. 56, 1, 111-159 (A), (1984).

24) Sansarricq, H. The general situation of leprosy in the world. Ethiop. Med. J. 20, 89-106, (1982).

\title{
多菌らい患者の多剤併用療法
}

\author{
N. M. SAMUEL, S. SAMUEL \\ (Anandaban Leprosy Hospital, Kathmandu, Nepal) \\ R. B. ADIGA \\ (Leprosy Services Development Board, Ministry of Health-HMG. Kathmandu, Nepal)
}

キーワード：併用化学療注, 薬剤而性, 再発, 形態及び菌指数

ネパールのアナンダバンらい病院において，380名の 多菌らい患者の多剤併用療法が行われた。併用療法に用 いられた薬剤はリファンピシン, DDS, クロファジミン (B663) およびィソプロディアン（INH，プロチオナミ ド, DDS の合剤) である。この治療は結核の短期化学 療法をモデルとしている。

全症例において臨床的にも細菌学的にも顕著な改善が 見られた。A群患者は24 32力月後にらい菌陰性となっ
た。一方，B群では36力月治療後においても，なお皮膚 塗抹標本で菌陽性であった。しかしながら，5薬剤を投 与したC群患者は明らかな臨床的, 細菌学的改善が示さ れた。クロファジミンによる変色で治療を中断した例は なかった。

我々の薬剤投与法は安全であり, 有効で, さらに経済 的であることが確められた。 